\title{
PEMODELAN NUMERIK PERILAKU KERUNTUHAN BALOK TINGGI BETON BERTULANG
}

\author{
Yosafat Aji Pranata ${ }^{1}$, Bambang Suryoatmono ${ }^{2}$ \\ ${ }^{1}$ Dosen Jurusan Teknik Sipil, Fakultas Teknik, Universitas Kristen Maranatha \\ Jalan Prof. drg. Suria Sumantri, MPH., No. 65, Bandung, Jawa Barat \\ E-mail : yosafat.ap@eng.maranatha.edu \\ ${ }^{2}$ Guru Besar, Program Pascasarjana, Universitas Katolik Parahyangan \\ Jalan Merdeka No. 30, Bandung, Jawa Barat
}

\begin{abstract}
Strut-and-tie model is design method based on D and B regions comprehension of reinforced concrete structures. Strut-and-tie model developed by Schlaich [Schlaich et al., 1987] at Uni-Stuttgart, Jerman. And then developed [Adebar et al., 1990; Jirsa et al., 1991; Reineck, 1996, 1999, 2002; ACI 318R, 2002, 2005, 2008]. Objectives of this research are to study strut-and-tie method for design of reinforced concrete deep beam, numerical simulation study using finite element method ADINA to found out parameters fir strut-and-tie method. Sample beam that used in this research is based on Hardjasaputra's deep beam experimentals report [Hardjasaputra, 2006]. Results from this research indicated that \%-relative difference (displacement) between ADINA simulation and experimental range from 25,49\%-27,71\%. \%-relative difference (z-strain) between ADINA simulation and experimental range from $10,53 \%-17,25 \%$. Value of uniaxial cut-off tensile stress $\left(\mathrm{f}_{\mathrm{ct}}\right)$ affect to ultimit load that can beam reached.
\end{abstract}

Keywords: Strut-and-tie model, Deep beam, Reinforced Concrete, Finite element method.

\begin{abstract}
ABSTRAK
Metode strut-and-tie model merupakan metode perencanaan struktur yang didasarkan pada pemahaman tentang adanya daerah D dan daerah B pada struktur beton bertulang. Untuk itu, metode strut-and-tie model dirintis oleh penelitian yang dilakukan oleh Schlaich [Schlaich et al., 1987] di Uni-Stuttgart, Jerman. Selanjutnya berkembang pesat [Adebar et al., 1990; Jirsa et al., 1991; Reineck, 1996, 1999, 2002; ACI 318R, 2002, 2005, 2008]. Tujuan penelitian ini adalah mempelajari metode strut-and-tie model untuk perencanaan balok tinggi beton bertulang, mempelajari simulasi numerik model benda uji dengan menggunakan metode elemen hingga dengan ADINA untuk mendapatkan parameter yang diperlukan dalam perencanaan metode strut-and-tie model. Model benda uji dalam penelitian ini diambil dari hasil penelitian eksperimental balok tinggi Hardjasaputra [Hardjasaputra, 2006]. Hasil penelitian memperlihatkan bahwa perbedaan \%_relatif lendutan balok hasil simulasi ADINA terhadap eksperimental berkisar antara 25,49\%-27,71\%. Perbedaan \%_relatif regangan-z hasil simulasi $A D I N A$ terhadap eksperimental berkisar antara 10,53\%-17,25\%. Penentuan nilai uniaxial cutoff tensile stress $\left(f_{c t}\right)$ berpengaruh terhadap beban ultimit yang dapat dicapai oleh balok.
\end{abstract}

Kata Kunci: Strut-and-tie model, Balok tinggi, Beton bertulang, Metode elemen hingga.

\section{PENDAHULUAN}

Perilaku keruntuhan struktur balok tinggi sangat perlu dipelajari untuk mengetahui kinerja struktur. Perilaku tersebut dapat diketahui dengan simulasi laboratorium melalui uji 
eksperimental benda uji struktur balok dengan riwayat pembebanan pada struktur sampai runtuh, atau melalui simulasi numerik metode elemen hingga dengan menggunakan perangkat lunak (software). Pada simulasi laboratorium, pemahaman yang benar mengenai idealisasi suatu struktur balok yang sebenarnya menjadi model yang akan diuji di laboratorium, teknik pemasangan strain gauges, model dan tipe beban, serta model tumpuan sangat berpengaruh terhadap hasil analisis yang diperoleh. Pemodelan dan simulasi dengan menggunakan perangkat lunak memerlukan pemahaman dasar teori dan konsep.

Tujuan dari penelitian dalam penulisan ini adalah mempelajari metode strut-and-tie model untuk perencanaan balok tinggi beton bertulang, mempelajari simulasi numerik metode elemen hingga pada model benda uji untuk mendapatkan parameter yang diperlukan dalam perencanaan strut-and-tie model, mempelajari perilaku keruntuhan balok tinggi beton bertulang, dan melakukan studi perbandingan hasil simulasi numerik metode elemen hingga pada model benda uji balok tinggi dengan hasil penelitian eksperimental Hardjasaputra [Hardjasaputra, 2006].

Penelitian menggunakan batasan/ruang lingkup model benda uji diambil dari hasil penelitian eksperimental balok tinggi beton bertulang yang dilakukan oleh Hardjasaputra [Hardjasaputra, 2006], perhitungan metode strut-and-tie model mengacu pada peraturan ACI 318R-08 [ACI, 2008], dan simulasi numerik model benda uji dengan metode elemen hingga dilakukan dengan menggunakan perangkat lunak ADINA. Parameter yang dipelajari yaitu deformasi, kekuatan strut diagonal, dan kuat ultimit balok. Pemodelan benda uji 2D (plane stress).

\section{TINJAUAN LITERATUR}

Balok tinggi adalah elemen struktur dengan beban pada suatu permukaan tertentu dan tumpuan pada permukaan lainnya, yang terletak pada posisi berlawanan, sehingga penunjang tekan dapat dikembangkan pada daerah antara beban dan tumpuan tersebut. Balok tinggi merupakan balok dengan kriteria perilaku keruntuhan geser. Balok dikategorikan sebagai balok tinggi apabila mempunyai panjang bentang bersih $\left(l_{n}\right)$ sama atau lebih kecil dibandingkan empat kali tingginya [ACI, 2008].

Metode strut-and-tie model merupakan metode perencanaan struktur yang didasarkan pada pemahaman tentang adanya daerah D dan daerah B pada struktur beton bertulang. Daerah B adalah bagian struktur yang penampangnya mempunyai distribusi 
regangan linier sehingga teori balok lentur klasik dapat diterapkan. Daerah D yaitu bagian struktur yang mengalami perubahan geometri atau bisa juga bagian yang ditempati beban terpusat yang menyebabkan pada bagian tersebut mempunyai distribusi regangan non-linier.

Suatu cara perencanaan yang merata dan konsisten untuk semua tipe struktur serta semua bagian struktur sangat diperlukan, konsep tersebut harus didasarkan pada model fisik yang realistis. Untuk itu, metode strut-and-tie model dirintis oleh penelitian yang dilakukan oleh Schlaich [Schlaich et al., 1987] di Uni-Stuttgart, Jerman. Selanjutnya berkembang pesat [Adebar et al., 1990; Jirsa et al., 1991; Reineck, 1996, 1999, 2002], sampai akhirnya diadopsi oleh American Concrete Institute pada peraturan ACI 318-02 [ACI, 2002]. Penelitian eksperimental di Indonesia antara lain telah dilakukan oleh Hardjasaputra [Hardjasaputra, 2006], yaitu penelitian eksperimental pembebanan sampai runtuh balok beton bertulang. Balok beton bertulang yang diuji mempunyai perbandingan bentang dan tinggi sebesar 2,25/0,8 = 2,8125, lebih besar dari 2,5 sehingga menurut kriteria ACI 318R-08 [ACI, 2008] sebenarnya belum termasuk kategori balok tinggi. Meskipun demikian dari perilaku keruntuhan yang diperlihatkan yaitu keruntuhan geser (diagonal splitting) maka dapat dikategorikan sebagai balok tinggi (deep-beam), yang mana perilakunya sangat berbeda dengan tipe balok biasa karena bukan keruntuhan lentur. Balok tinggi tersebut mempunyai bentuk balok biasa persegi, sebelum diuji ditanamkan beberapa strain ganges dan selanjutnya dilakukan uji beban sampai mencapai kondisi runtuh. Selama pembebanan, regangan dan lendutan dicatat secara otomatis dalam alat ukur elektronik, pola retak pada balok digambar secara manual. Dengan demikian dapat diperoleh informasi tentang perilaku keruntuhan balok tinggi.

Daerah B dan D dari beberapa tipe balok yang diberi beban terpusat dan beban merata diperlihatkan pada Gambar 2.3. Daerah D atau daerah B terbentuk karena dipengaruhi rasio tinggi terhadap bentang, adanya perubahan geometri struktur yang menyolok, tipe beban, dan lokasi tumpuan. Konfigurasi geometri dan beban menentukan daerah D maupun daerah B.
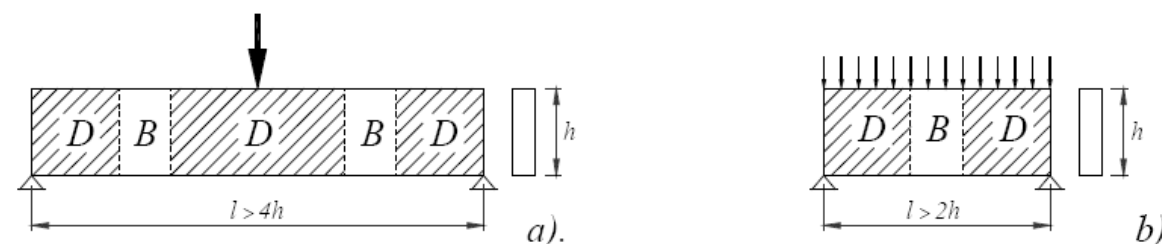

Gambar 2.3 Daerah B dan D [Schlaich et al., 1987] 
Untuk struktur yang pernah dianalisis dengan strut-and-tie model tentu saja model truss-nya dapat ditiru kembali, karena bagaimanapun juga model truss tersebut adalah sudah tertentu. Untuk struktur baru, pemakaian perangkat lunak metode elemen hingga dengan elemen dua dimensi (membran atau shell) dapat membantu memperlihatkan aliran gaya-gaya berdasarkan trajektori tegangan elastiknya, dari situ kemudian dapat diperkirakan lokasi penempatan strut dan tie, Schlaich secara detail memberikan tahapan-tahapan dalam penyusunan model strut-and-tie model dari beberapa model struktur [Schlaich et al., 1987].

Dimensi yang digunakan untuk mengevaluasi komponen rangka batang (truss) pada dasarnya hanya berupa model, sementara bentuk fisik tidak seperti itu. Oleh karena itu perlu diketahui berapa tegangan efektif sebenarnya yang bekerja pada komponen tersebut.

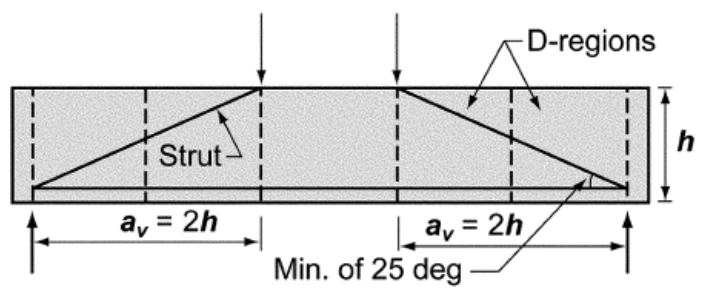

(b) Shear span, $\mathbf{a}_{\boldsymbol{v}}=\mathbf{2} \boldsymbol{h}$, limit for a deep beam

\section{Gambar 2.4 Balok Tinggi [ACI, 2008]}

Ketentuan-ketentuan perencanaan komponen-komponen strut-and-tie model diatur pada Appendix A “Strut-and-Tie Models” ACI 318R-08 [ACI, 2008], dalam segala hal harus memenuhi persyaratan kekuatan sebagai berikut:

$$
\phi \cdot F_{n} \geq F_{u}
$$

Kekuatan strut dihitung berdasarkan Persamaan 2.2.

$$
\begin{aligned}
& F_{n s}=f_{c e} \cdot A_{c s} \\
& f_{c e}=0,85 \cdot \beta_{s} \cdot f_{c}^{\prime}
\end{aligned}
$$

Kekuatan tie dihitung berdasarkan Persamaan 2.4.

$$
F_{n s}=A_{s t} \cdot f_{y}
$$

Kekuatan area titik nodal dihitung berdasarkan Persamaan 2.5.

$$
\begin{aligned}
& F_{n n}=f_{c e} \cdot A_{n z} \\
& f_{c e}=0,85 \cdot \beta_{n} \cdot f_{c}^{\prime}
\end{aligned}
$$


Implementasi simulasi numerik model benda uji dengan metode elemen hingga dengan pemodelan nonlinier pada perangkat lunak ADINA dilakukan secara terpisah antara perilaku material dengan elemen. Untuk mempelajari perilaku material, maka digunakan fitur material khusus yang telah tersedia pada perangkat lunak ADINA yaitu material beton. Sedangkan model elemen menggunakan model solid 2D, sehingga analisis menggunakan pendekatan plane stress. Pemodelan baja tulangan dalam penelitian ini dilakukan dengan menggunakan fitur elemen solid 2D yang dikombinasikan dengan perilaku material bilinier baja. Ilustrasi penjelasan elemen solid ditampilkan pada Gambar 2.7, penjelasan asumsi dasar plane stress ditampilkan pada Gambar 2.8.

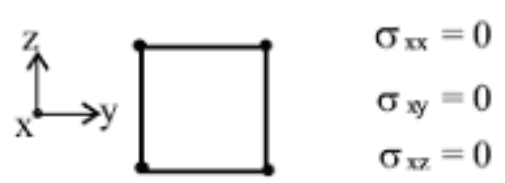

a) Plane stress element

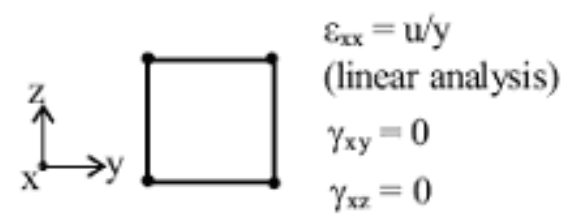

c)Axisymmetric element

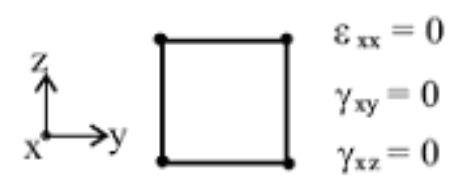

b) Plane strain element

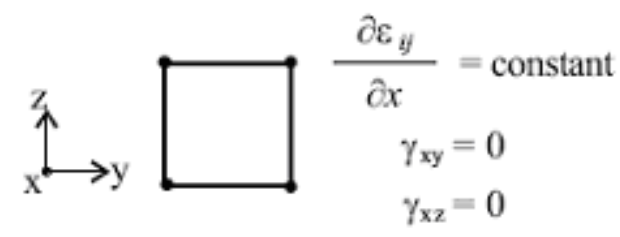

d) Generalized plane strain

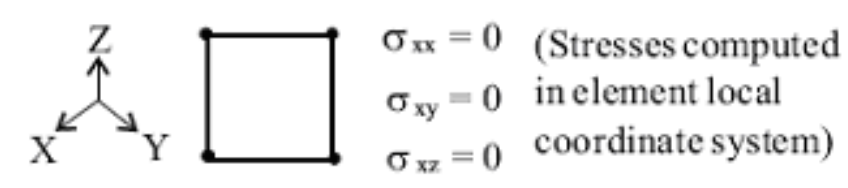

e) 3-D plane stress element

Gambar 2.8 Asumsi Dasar pada Analisis 2 Dimensi [ADINA, 2005]

Properti tulangan baja ditetapkan sebagai suatu hubungan tegangan-regangan tunggal untuk mendefinisikan bahan material. Kurva hubungan tegangan-regangan dari tulangan baja yang digunakan untuk perencanaan struktur beton diperoleh dari uji tulangan yang dibebani secara monotonik tarik. 


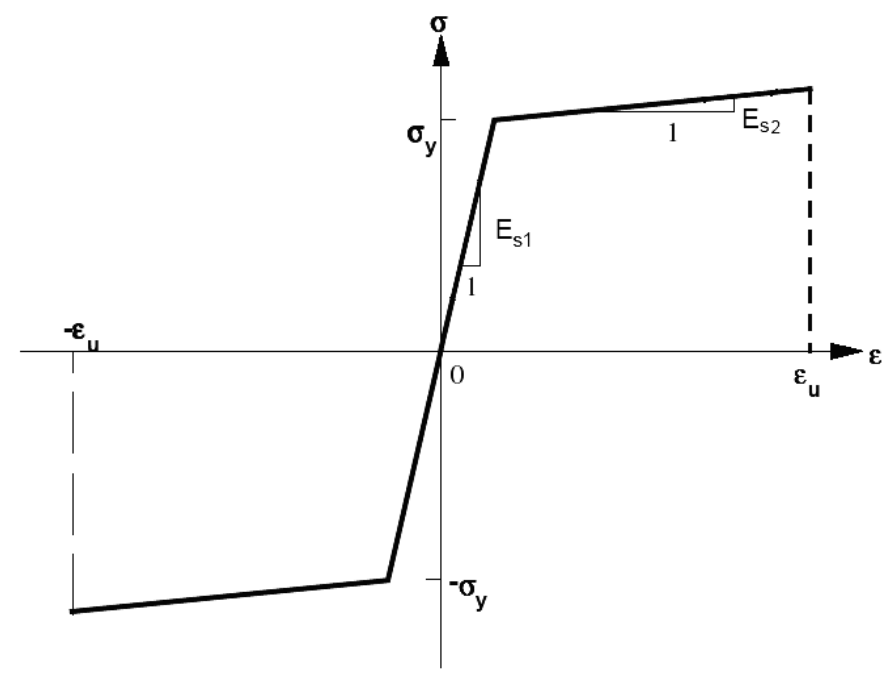

Gambar 2.9 Kurva Tegangan-Regangan Baja Tulangan [ADINA, 2005]

Material beton dalam perangkat lunak ADINA dianggap benar-benar untuk memodelkan beton itu sendiri tanpa memasukkan parameter baja tulangan. Model material ini disebut concrete model [ADINA, 2005].

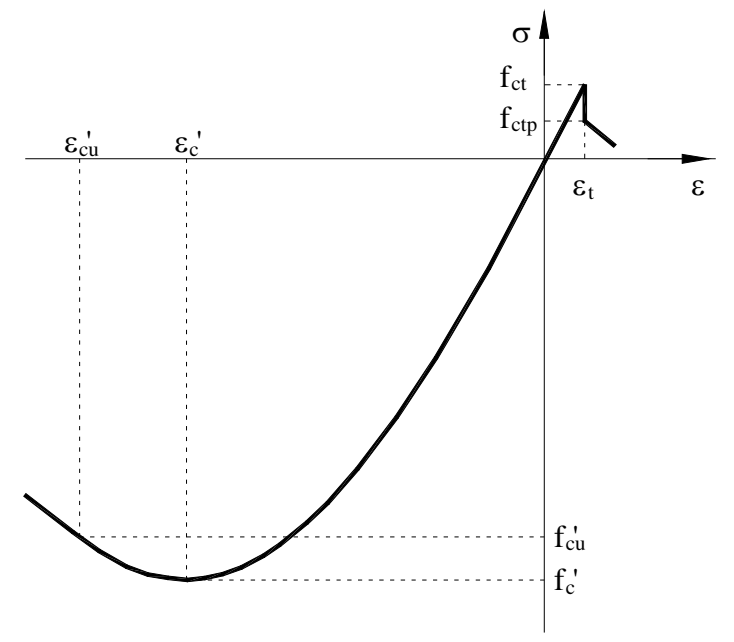

Gambar 2.10 Hubungan Tegangan-Regangan Uniaksial Beton [ADINA, 2005]

\section{STUDI KASUS DAN PEMBAHASAN}

Studi kasus dalam penelitian ini menggunakan model balok tinggi beton bertulang hasil penelitian eksperimental balok tinggi [Hardjasaputra, 2006]. Material yang digunakan yaitu baja tulangan dengan properti tegangan leleh $\left(f_{y}\right)$ sebesar 435 MPa dan beton dengan 
kuat tekan $\left(f_{c}^{\prime}\right.$ ') sebesar $37 \mathrm{MPa}$. Proses uji eksperimental yang telah dilakukan adalah pengujian balok tinggi dengan riwayat pembebanan secara bertahap sampai dengan runtuh. Tahapan wiwayat waktu pembebanan dibagi kedalam tiga tahap, yaitu beban sebesar 300 kN, $600 \mathrm{kN}$ dan $1100 \mathrm{kN}$.

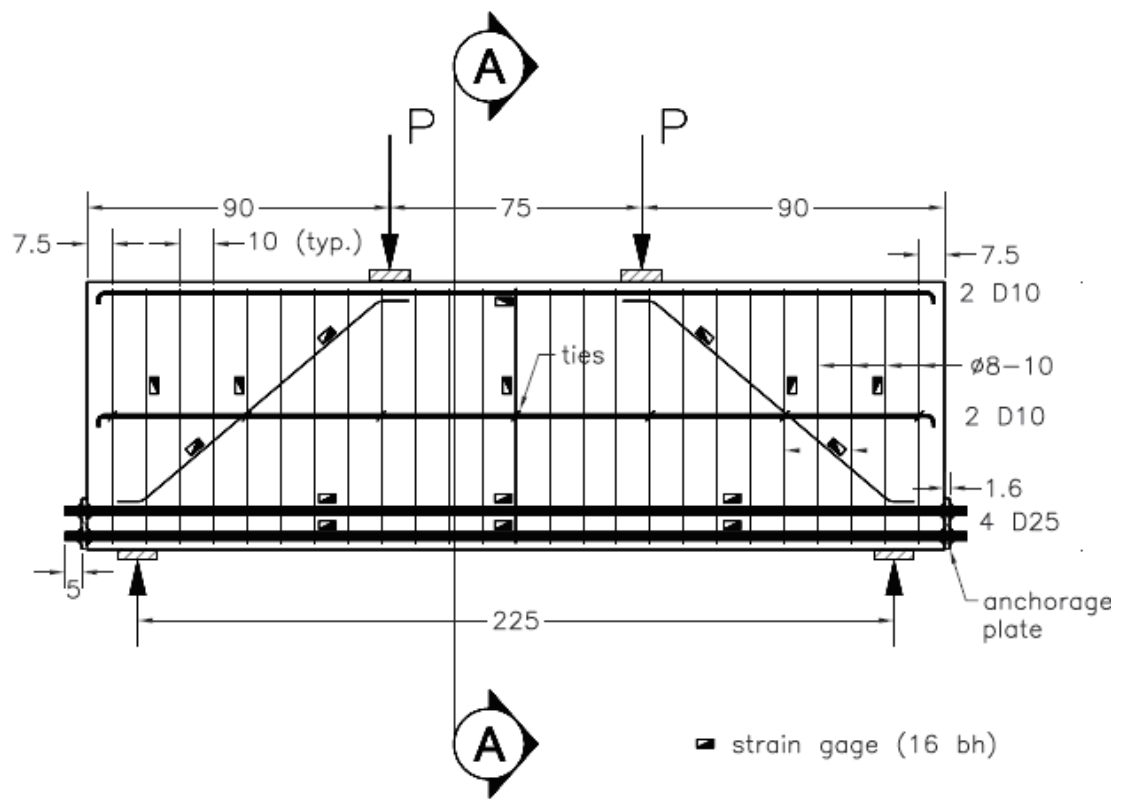

Gambar 3.1 Detail Dimensi dan Penulangan Balok Tinggi [Hardjasaputra, 2006]

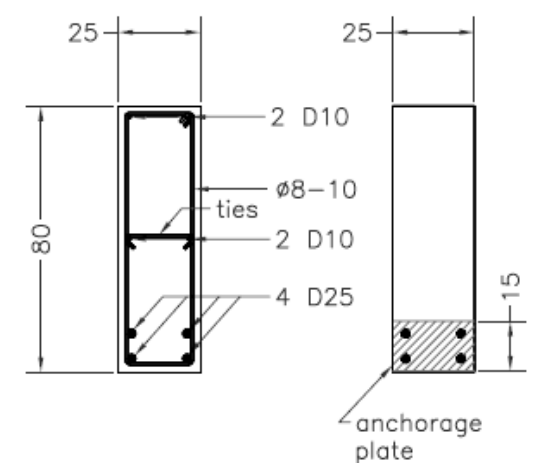

Gambar 3.2 Potongan A-A [Hardjasaputra, 2006]

Data hasil uji eksperimental, yaitu hasil pembacaan LVDT selengkapnya ditampilkan pada

Tabel 3.1, dan hasil pembacaan strain gauges selengkapnya ditampilkan pada Tabel 3.2. 


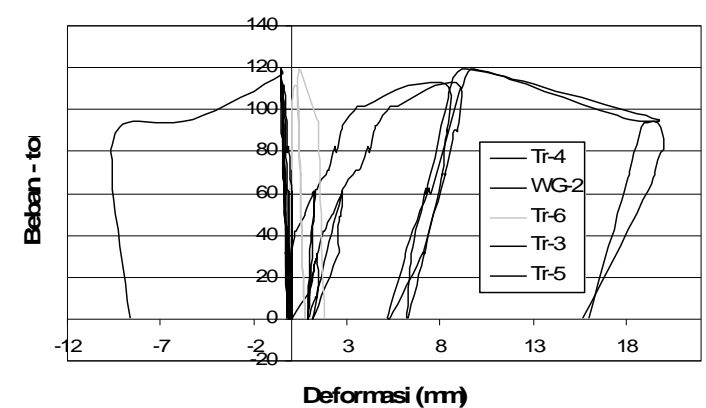

(a). Kurva beban-deformasi

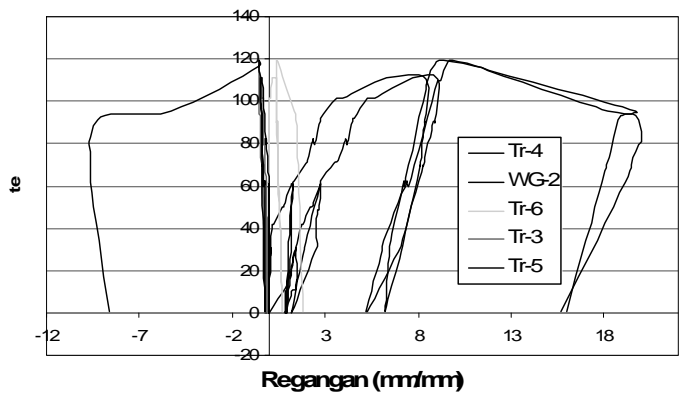

(b). Kurva regangan-waktu

Gambar 3.4 Kurva Hasil Uji Eksperimental [Hardjasaputra, 2006]

\subsection{Perhitungan dengan Metode strut-and-tie model}

Perhitungan dengan metode strut-and-tie model dilakukan secara manual berdasarkan persamaan analitis. Tahapan perhitungan meliputi cek kapasitas penunjang (area titik nodal) di daerah pembebanan dan tumpuan, pemilihan model strut-and-tie untuk desain, isolasi daerah terganggu (disturbed region), pemilihan tulangan, perhitungan strut tekan diagonal, dan cek kapasitas, dan penulangan.

Prediksi besar beban ultimit $P_{u}$ adalah sebesar $568 \mathrm{kN}$ [Hardjasaputra, 2006]. Perhitungan analitis dilakukan tanpa memperhitungkan faktor $\phi$, hasil yang diperoleh dibandingkan terhadap hasil uji eksperimental.

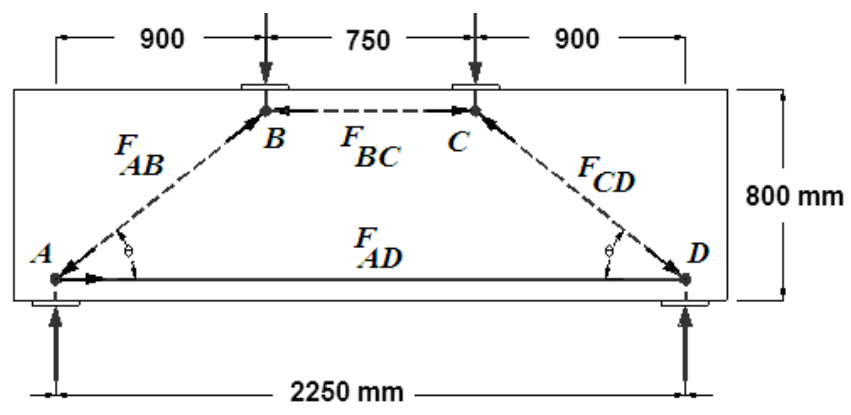

Gambar 3.8 Model Strut-and-tie untuk Desain.

\section{Perhitungan Kekuatan Area Titik Nodal}

Perhitungan kekuatan area titik nodal di lokasi pembebanan $\left(\beta_{n}=1,0\right.$ untuk tipe CCC) dengan Persamaan 2.5. 


$$
F_{n n}=0,85 \cdot 1,0 \cdot 37 \cdot 150 \cdot 250=1179375 \mathrm{~N}=1179,375 \mathrm{kN}
$$

Perhitungan kekuatan area titik nodal di lokasi tumpuan $\left(\beta_{n}=0,8\right.$ untuk tipe CCT) dengan Persamaan 2.5.

$$
F_{n n}=0,85 \cdot 0,8 \cdot 37 \cdot 150 \cdot 250=943500 \mathrm{~N}=943,5 \mathrm{kN}
$$

Hasil perhitungan menunjukkan bahwa kekuatan area titik nodal di lokasi pembebanan dan tumpuan lebih besar daripada prediksi beban ultimit.

\section{Perhitungan Kekuatan Strut BC dan Tie AD}

Perhitungan strut BC menggunakan Persamaan 2.3 dan tie AD menggunakan Persamaan 2.4. Besarnya gaya (beban) terfaktor $F_{A D}$ dan $F_{B C}$ dapat dihitung dengan menggunakan persamaan keseimbangan momen pada titik A.

$$
\begin{aligned}
& \sum M_{A}=0 \\
& F_{B C}=\frac{511200000}{800-1,125 \cdot w_{c}}
\end{aligned}
$$

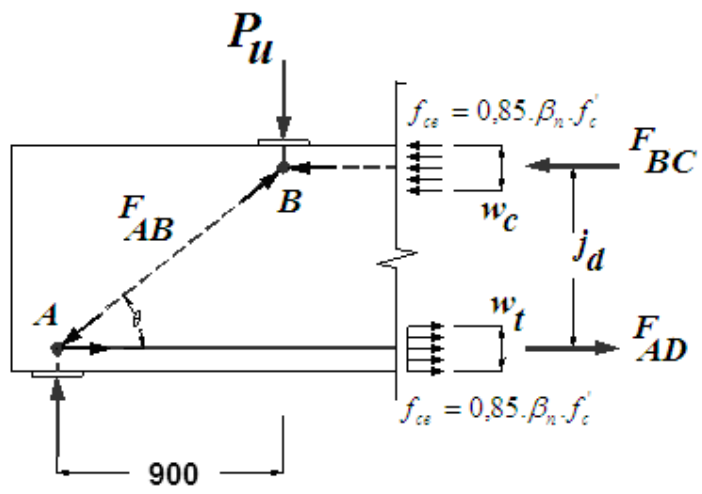

Gambar 3.9 Perencanaan Kekuatan Strut dan Tie [Hardjasaputra, 2006]

Besarnya beban terfaktor $F_{B C}$ dihitung sebagai berikut,

$$
\begin{aligned}
& F_{B C}=\frac{511200000}{800-1,125 \cdot w_{c}}=743563,64 \mathrm{~N}=743,56 \mathrm{kN} \\
& F_{A D}=F_{B C}=743,56 \mathrm{kN}
\end{aligned}
$$

Selanjutnya dilakukan perhitungan cek kapasitas kekuatan strut BC dengan Persamaan 2.2.

$$
F_{n s}=0,85 \cdot 1,0 \cdot 37 \cdot(250 \cdot 100)=786250 \mathrm{~N}=786,25 \mathrm{kN}
$$

Hasil perhitungan menunjukkan bahwa kekuatan desain strut BC $\left(F_{n s}\right)$ lebih besar daripada beban terfaktor strut $\mathrm{BC}\left(F_{B C}\right)$. 
Sedangkan perhitungan tie AD dilakukan menggunakan Persamaan 2.4.

$$
F_{n s}=A_{s t} . f_{y}=1962,5.435=853687,5 \mathrm{~N}=853,69 \mathrm{kN}
$$

Hasil perhitungan menunjukkan bahwa kekuatan tie AD lebih besar daripada beban terfaktor tie $A D$.

\section{Perhitungan kekuatan strut AB}

Maka dapat dihitung gaya strut tekan diagonal $\left(F_{A B}\right)$,

$$
F_{A B}=\frac{568000}{\sin 40,675^{\circ}}=871477,42 \mathrm{~N}=871,477 \mathrm{kN}
$$

Lebar strut pada bagian atas,

$$
w_{c t}=250 \cdot \sin 40,675^{\circ}+100 \cdot \cos 40,675^{\circ}=238,784 \mathrm{~mm}
$$

Lebar strut pada bagian bawah,

$$
w_{c b}=250 \cdot \sin 40,675^{\circ}+125 \cdot \cos 40,675^{\circ}=257,74 \mathrm{~mm}
$$

Selanjutnya dilakukan perhitungan (cek) kapasitas strut $\mathrm{AB}\left(\beta_{s}=0,75\right)$,

$$
F_{n s}=0,85 \cdot 0,75 \cdot 37 \cdot(250 \cdot 238,784)=1408079,4 \mathrm{~N}=1408,08 \mathrm{kN}
$$

Hasil perhitungan menunjukkan bahwa kekuatan desain strut AB lebih besar daripada beban terfaktor strut $\mathrm{AB}$.
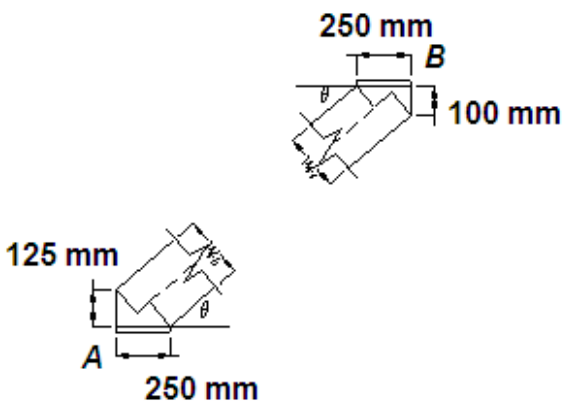

Gambar 3.10 Detail Titik A dan Titik B [Hardjasaputra, 2006]

\subsection{Analisis Model Benda Uji dengan Metode Elemen Hingga}

Model benda uji mempunyai bentuk simetris, demikian pula dua beban terpusat diletakkan simetris (Gambar 3.1), maka sesuai prinsip simetri struktur [Cook et al., 2004] pemodelan benda uji dibuat setengah bentang pada perangkat lunak ADINA. Pemodelan tumpuan benda uji dimodelkan sebagai rol (translasi yang terjadi arah-y dan tidak terjadi 
translasi arah-z) pada titik nodal 7. Karena menggunakan prinsip pemodelan simetri struktur, maka pada garis 58, 59, 60, 61, 62, 63, 64, 65, 66 dimodelkan sebagai tumpuan rol dengan translasi yang terjadi hanya pada arah-z (tidak terjadi translasi arah-y).

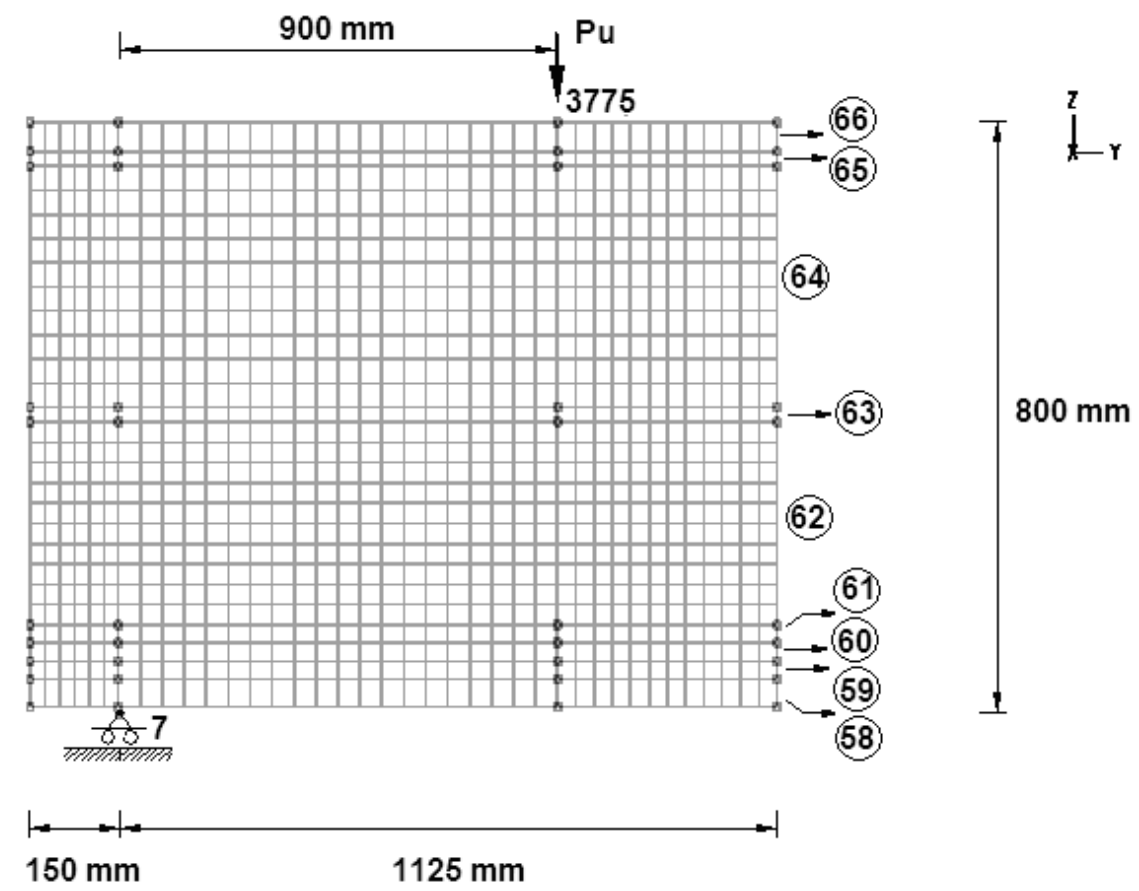

Gambar 3.11 Idealisasi Struktur

Pemodelan seperti terlihat pada Gambar 3.11 dilakukan berdasarkan dimensi panjang bentang dan tinggi balok. Untuk menempatkan elemen truss sebagai simulasi baja tulangan maka strategi pemodelan dilakukan dengan menggunakan bantuan penempatan objek-objek berupa titik nodal (node) dan garis (line), dengan jarak disesuaikan berdasarkan detail gambar struktur (Gambar 3.1). Sedangkan pemodelan beton menggunakan objek surface dengan elemen Solid 2D.

Pemodelan properti material baja, parameter data masukan yaitu nilai modulus elastisitas baja $(E)$ sebesar $200000 \mathrm{MPa}$ dan tegangan leleh baja $\left(f_{y}\right)$ sebesar $435 \mathrm{MPa}$.

Parameter data masukan pada pemodelan properti material beton perangkat lunak ADINA adalah sebagai berikut:

1. Parameter nilai rasio Poisson, pada penelitian ini digunakan $v=0,2$.

2. Parameter uniaksial tekan beton, yaitu:

a. Kuat tekan maksimum $f_{c}{ }^{\prime}=37 \mathrm{MPa}$ 
b. Kuat tekan ultimit [ACI, 2008] yaitu $f_{c u}{ }^{\prime}=0,85 . f_{c}{ }^{\prime}=31,45 \mathrm{MPa}$

c. Regangan tekan uniaksial $\varepsilon_{c u}=0,0025$

3. Parameter uniaksial tarik beton, yang berpengaruh pada balok beton bertulang dengan keruntuhan geser. Dalam penelitian ini, nilai Post Cracking Tensile Stress $\left(f_{c t p}\right)$ nilainya sama dengan nilai Uniaxial Cut-Off Tensile Stress $\left(f_{c t}\right)$, yaitu dihitung berdasarkan Persamaan 11 [Bresler et al., 1963].

$$
f_{c t}=0,33 \cdot \sqrt{f_{c}^{\prime}}
$$

4. Parameter critical strain constant $C_{1}$ dan $C_{2}$ adalah untuk menentukan batas keruntuhan material (material failure envelopes) dalam kondisi tegangan multiaksial, yaitu keruntuhan tarik (tensile) atau tekan (crushing) berdasarkan data uniaksial. Dalam penelitian ini digunakan nilai default [ADINA, 2005].

\section{Pemodelan Beban dan Material}

Pemodelan beban ditampilkan pada Gambar 3.15. Beban berupa beban terpusat yang ditempatkan pada titik nodal 11 (Gambar 3.11) dengan arah beban yaitu vertikal ke bawah, maka digunakan arah beban sumbu-z negatif.

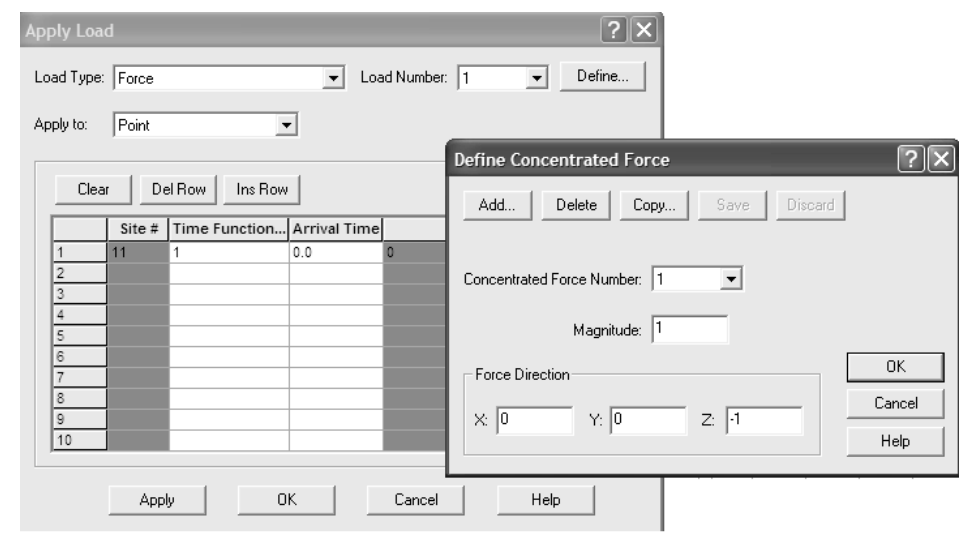

Gambar 3.15 Pemodelan Beban ADINA [ADINA, 2005]

Besarnya beban ultimit $\left(P_{u}\right)$ hasil penelitian Hardjasaputra adalah sebesar 568 kN. Dalam penelitian ini, beban ditingkatkan berdasarkan riwayat waktu pembebanan, dengan tujuan untuk mendapatkan simulasi keruntuhan balok. Oleh karena itu target beban maksimum sebagai parameter data masukan adalah sebesar $568 \mathrm{kN}$. 


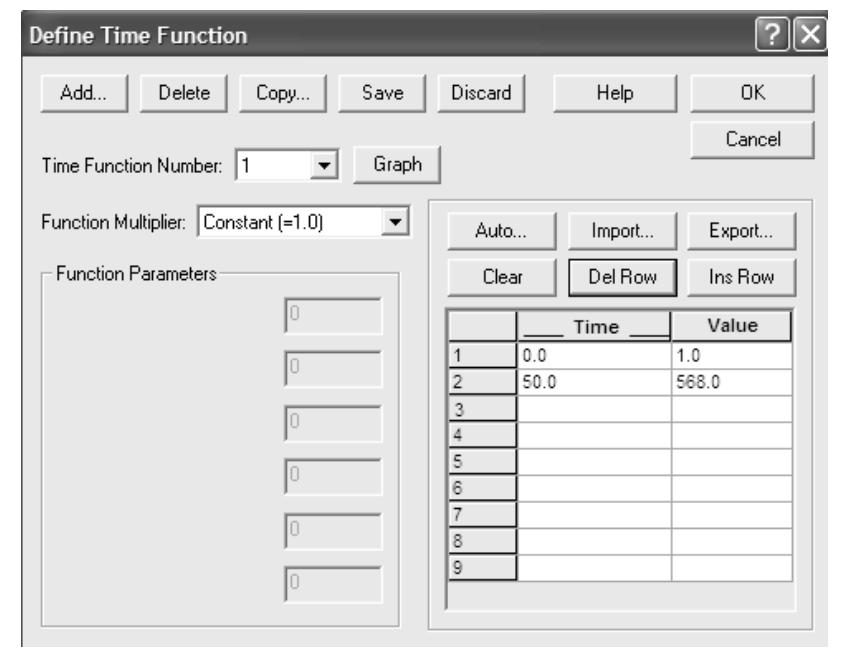

Gambar 3.16 Fungsi Waktu Pembebanan [ADINA, 2005]

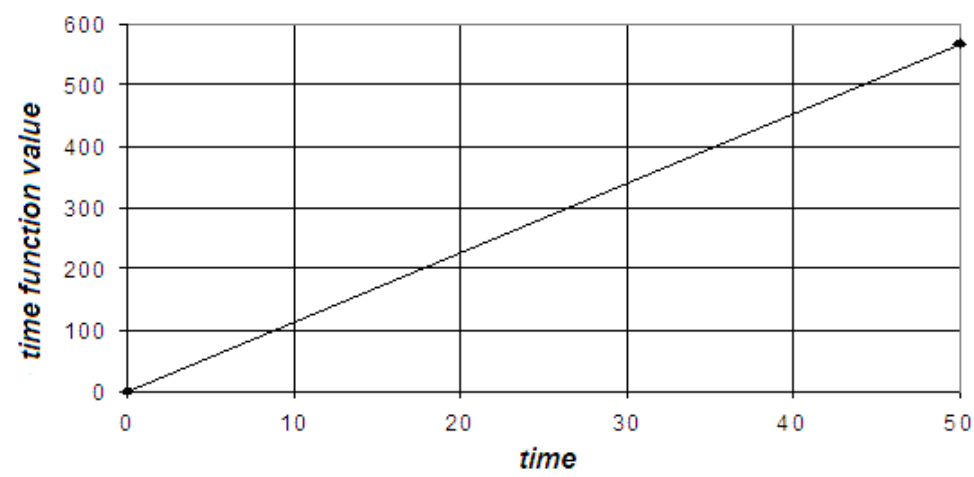

Gambar 3.17 Kurva Fungsi Waktu

Pemodelan elemen solid 2D sebagai data untuk simulasi baja tulangan dan simulasi beton ditampilkan pada Gambar 3.18, untuk baja tulangan digunakan model properti plastic bilinear (Gambar 3.14) dan untuk beton digunakan model properti concrete (Gambar 3.13). Dalam penelitian ini, asumsi yang digunakan dalam analisis bond adalah tidak terjadi slip.

\section{Pembahasan}

Dalam penelitian ini pembahasan hasil analisis meliputi peralihan dan regangan arah sumbu-z pada tinjauan beberapa titik, simulasi keruntuhan balok, tegangan pada strut diagonal, dan tegangan dan deformasi pada area titik nodal.

Peralihan yang ditinjau dalam penelitian ini adalah hasil uji eksperimental pada empat lokasi titik pemasangan LVDT yaitu TR4, TR8, dan TR9 (Gambar 3.3 dan data pada 
Tabel 3.1), yang selanjutnya dibandingkan terhadap hasil simulasi $A D I N A$ pada lokasi titik yang sama.

Hasil selengkapnya ditampilkan pada Tabel 3.3. Perbedaan \%-relatif antara simulasi ADINA terhadap hasil eksperimental berkisar antara 25,49\% sampai dengan 27,71\%.

Tabel 3.3 Peralihan-z

\begin{tabular}{|c|c|c|c|c|}
\hline \multicolumn{2}{|c|}{ Eksperimental } & \multicolumn{2}{c|}{ ADINA } & \multirow{2}{*}{ \%-relatif } \\
\cline { 1 - 4 } LVDT & peralihan (mm) & Titik nodal & peralihan (mm) & \\
\hline TR4 & 11,055 & 414 & 8,051 & 27,17 \\
\hline TR8 & 10,800 & 171 & 8,047 & 25,49 \\
\hline TR9 & 4,320 & 45 & 5,517 & 27,71 \\
\hline
\end{tabular}
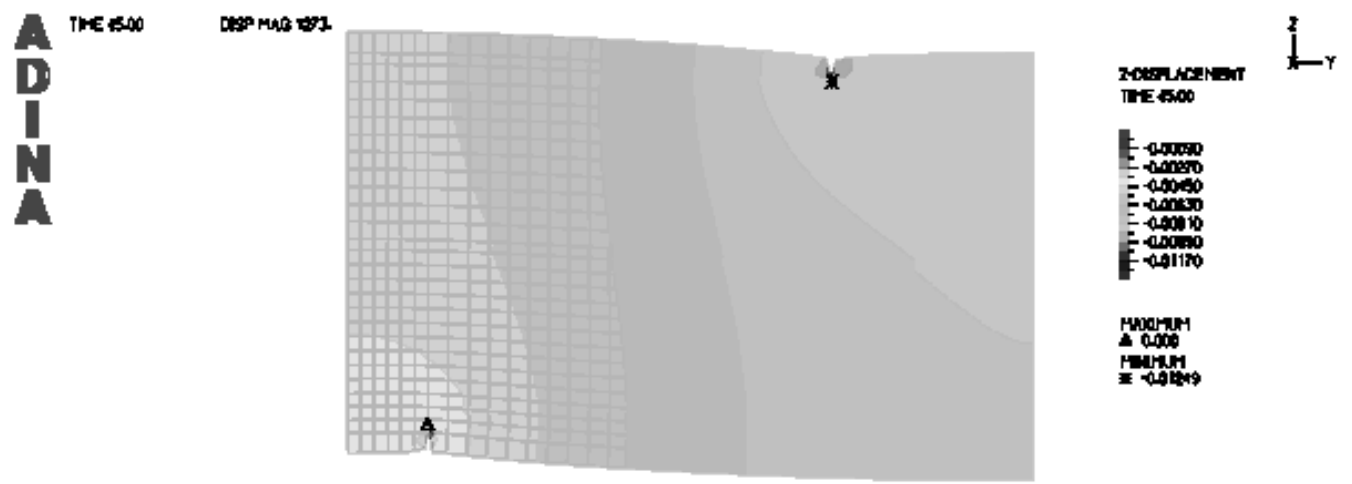

Gambar 3.19 Peralihan Sumbu-z

Hasil simulasi $A D I N A$ untuk nilai regangan sumbu-z ditinjau elemen 23, 61, 38, dan 76, selanjutnya dibandingkan terhadap hasil uji eksperimental pada lokasi yang sama, yaitu tinjauan strain gauges 5, 6, 9, dan 10 berdasarkan data pada Tabel 3.2. Hasil perhitungan selengkapnya ditampilkan pada Tabel 3.4. Perbedaan \%-relatif antara simulasi ADINA terhadap hasil eksperimental berkisar antara 10,53\% sampai dengan 17,25\%.

Tabel 3.4 Regangan-z

\begin{tabular}{|c|c|c|c|c|}
\hline \multicolumn{2}{|c|}{ Eksperimental } & \multicolumn{2}{c|}{ ADINA } & \%-relatif \\
\cline { 1 - 3 } Strain gauge & regangan & Elemen & regangan & \\
\hline 5 & 0,003070 & 61 & 0,00347 & 13,03 \\
\hline 6 & 0,001194 & 23 & 0,000898 & 17,25 \\
\hline 9 & 0,000966 & 76 & 0,000808 & 16,36 \\
\hline 10 & 0,000285 & 38 & 0,000255 & 10,53 \\
\hline
\end{tabular}




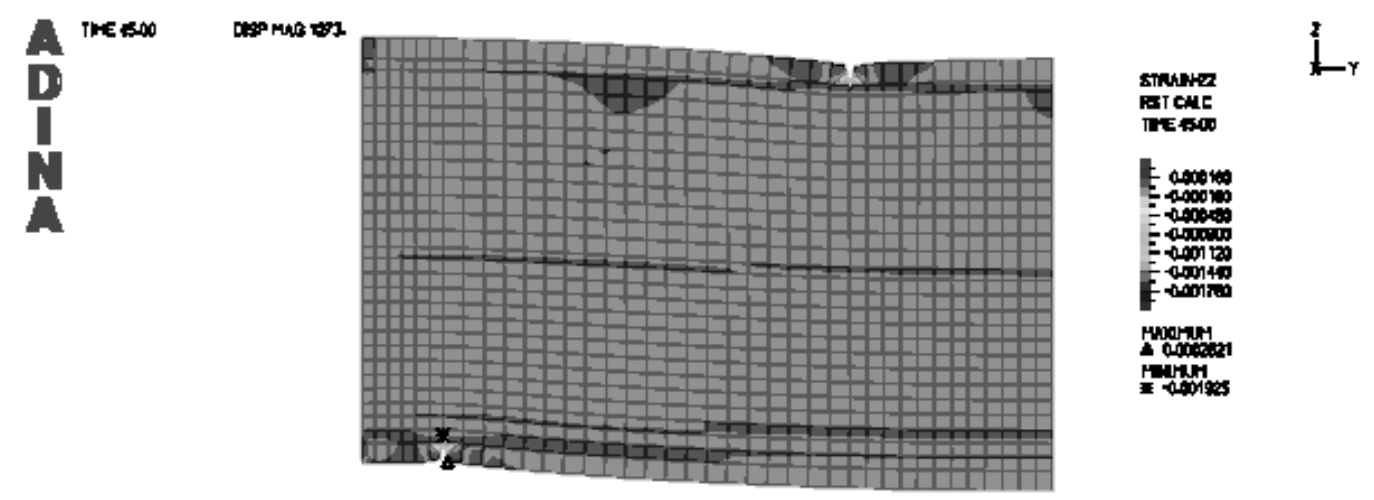

Gambar 3.20 Regangan sumbu-z

Parameter yang dibutuhkan dalam perencanaan dengan metode strut-and-tie model yaitu tegangan maksimum pada strut AB. Dari simulasi ADINA diperoleh hasil tegangan arah sumbu-z, yaitu pada daerah strut diagonal (elemen 862) yaitu sebesar 25,513 MPa. Sedangkan menurut rekomendasi dari Hardjasaputra [Hardjasaputra, 2006] berdasarkan hasil uji eksperimental, besarnya tegangan pada daerah strut diagonal yaitu sebesar 0,51. $f_{c}$, (pendekatan dengan Metode ACI 318-2002) atau sebesar 18,87 MPa. Maka perbedaan \%relatif antara hasil simulasi $A D I N A$ dengan eksperimental adalah sebesar 35,2\%.

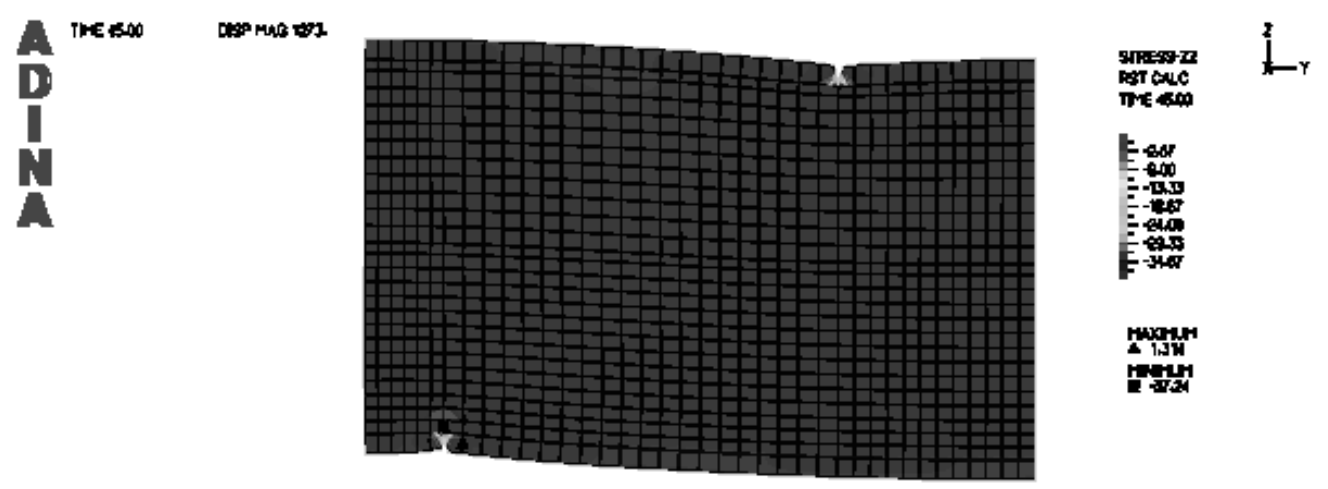

Gambar 3.22 Tegangan pada Strut AB

Sedangkan nilai regangan pada strut diagonal $\mathrm{AB}$ dengan simulasi ADINA diperoleh sebesar $0,000982 \mathrm{~mm} / \mathrm{mm}$ atau lebih besar 30,93\% dibandingkan hasil uji eksperimental Hardjasaputra yaitu 0,00075 mm/mm [Hardjasaputra, 2006]. 


\section{KESIMPULAN}

Kesimpulan yang dapat diambil dari penelitian ini adalah sebagai berikut:

1. Simulasi $A D I N A$ dapat digunakan untuk memprediksi lendutan balok dengan tingkat ketelitian berkisar antara 25,49\%-52,57\%. lebih besar dibandingkan hasil eksperimental.

2. Simulasi $A D I N A$ dapat digunakan untuk memprediksi regangan arah sumbu-z dengan tingkat ketelitian berkisar 10,53\%-17,25\% lebih besar daripada hasil eksperimental.

3. Penentuan nilai uniaxial cut-off tensile stress $\left(f_{c t}\right)$ berpengaruh terhadap beban ultimit yang dapat dicapai oleh balok. Hal ini mengindikasikan bahwa besarnya kuat tarik material beton masih mengandalkan rumus empiris berdasarkan dari kuat tekan beton.

4. Untuk mempelajar beban runtuh dari struktur balok beton bertulang maka informasi kurva beban-lendutan selama riwayat pembebanan struktur sangat diperlukan.

\section{DAFTAR PUSTAKA}

1. ADINA R\&D, Inc. 2005. ADINA Theory and Modelling Guide, Volume 1, ADINA R\&D, Inc., 71 Elton Ave., Watertown, MA 02472, USA.

2. American Concrete Institute. 2008. Building Code Requirements for Structural Concrete (ACI 318-08) and Commentary - An ACI Standard, American Concrete Institute Committee 318.

3. Bresler. B., Scordelis A.C. 1963. Shear Strength of Reinforced Concrete Beam, Journal American Concrete Institute, 60(1), 51-72, 1963.

4. Cook, R.D., Malkus, D.S., Plesha, M.E., Witt, R.J. 2004. Concepts and Applications of Finite Element Analysis, John Wiley \& Sons, Inc.

5. Dewobroto, W. 2005. Simulasi Keruntuhan Balok Beton Tanpa Sengkang dengan Metode Elemen Hingga, Seminar Bidang Kajian 2, Program Pascasarjana, Program Doktor Ilmu Teknik Sipil, Universitas Katolik Parahyangan, Bandung.

6. Harjasaputra, H. 2006. Consistent Strut-and-Tie Modelling for Full Scale Testing of Three Deep Beams With and Without Opening, $2^{\text {nd }}$. Asian Concrete Federation Conference, Bali, Indonesia, November 20-21, 2006.

7. Kwak, H.G., Filippou, F.C. 1990. Finite Element Analysis Of Reinforced Concrete Structures Under Monotonic Loads, Report No. UCB/SEMM-90/14, UC-Berkeley, California, 1990. 
8. MacGregor, J.G. 2002. Part 2: Derivation of strut-and-tie models for 2002 ACI Code, p.7 - 40, in: SP 208 - Examples for the Design of Structural Concrete with Strut-and-Tie Models: K.H. Reineck (Ed.)., American Concrete Institute, Farmington Hills, Michigan.

9. Reineck, K.H. 2002. SP-208: Examples for the Design of Structural Concrete with Strut-and-Tie Models, American Concrete Institute, Farmington Hills, Michigan, $242 \mathrm{pp}$.

10. Schlaich, J., Schafer, K., Jennewein, M. 1987. Toward a Consistent Design of Structural Concrete (Special Report), PCI Journal, Vol. 32, No. 3, May-June, 178 pp.

11. Standar Nasional Indonesia. 2002. SNI-03-2847-2002 - Tata Cara Perhitungan Struktur Beton Untuk Bangunan Gedung, Standar Nasional Indonesia. 